\title{
Cikkismertetés: A Föld egészséges és fenntartható táplálkozási rendszere
}

\author{
Article review: The healthy and sustainable food systems of the Earth
}

Ismertető: $\quad$ Bíróné Asbóth Katalin $\square$

Heim Pál Országos Gyermekgyógyászati Intézet, Módszertani lgazgatóság, Budapest

Ismertetett cikk: Willett W, Rockström J, Loken B, et al. Food in the Anthropocene: the EAT - Lancet Commission on healthy diets from sustainable food systems. Lancet. 2019 Feb 2;393(10170):447-492. doi: 10.1016/S0140-6736(18)31788-4

Beküldve: $\quad$ 2019. 04. 29.

doi: $\quad$ 10.24365/ef.v60i4.465

Kulcsszavak: fenntartható táplálkozási rendszerek; ökoszisztéma; biztonságos múködési tér; Föld egészsége étrend tányérja

Keywords: sustainable food systems; ecosystem; safe operating space; planetary healthy-diet plate

\section{BEVEZETÉS}

Óriási kihívást jelent az emberiségnek, hogy a növekvő globális népesség számára fenntartható forrásokból biztosítson egészséges élelmiszereket. A mind az egyén, mind a bolygó egészségét biztosító táplálkozásra való áttérés 2050-ig alapvető dietetikai változást igényel. A gyümölcs, zöldség, olajos magvak és hüvelyesek globális fogyasztása meg kell, hogy duplázódjon, míg a vörös húsok és a cukor fogyasztását felére kell csökkenteni. A növényi alapanyagú és kevés állati összetevőt tartalmazó étrend nemcsak eleget tesz a korszerú táplálkozás kívánalmainak, hanem azon törekvésnek is, hogy kedvező hatással bírjon a környezetre.
Jelenleg, az ún. antropocén korban a fenntartható forrásból származó egészséges étrend biztosítása jelenti a legnagyobb kihívást mind a növekvő népesség, mind pedig a bolygó számára.' Beavatkozás nélkül azt kockáztatjuk, hogy nem érjük el sem az Egyesült Nemzetek Szövetségének (ENSZ) Fenntartható Fejlesztési Céljait (Sustainable Development Goals, SDGs), sem pedig a Párizsi Egyezmény célkitúzéseit - így félő, hogy a ma gyermekei olyan bolygót örökölnek, mely súlyosan sérült, és amelyen a népesség nagy része egyre inkább a rossz táplálkozástól és megelőzhető betegségektől szenved. ii,iii A táplálkozás az egyedüli legerősebb eszköz az emberi egészség és a környezeti fenntarthatóság optimalizálására a Földön.

\footnotetext{
' Javasolt új geológiai korszakot kezdeni, melynek jellemzője, hogy az emberiség a változás uralkodó ereje a bolygón.

ii Az ENSZ minden tagországa által 2015-ben elfogadott, 2030-ig szóló Fenntartható Fejlesztési Céljairól (SDGs) bővebben: https://sustainabledevelopment.un.org/?menu=1300

iii A Párizsi Egyezmény az ENSZ tagállamok körében 2018.október 22-én életbe lépett megállapodás a klímaváltozás elleni küzdelem érdekében: https://unfccc.int/process-and-meetings/the-paris-agreement/the-paris-agreement
} 


\section{RÉSZLETES ISMERTETÉS}

Míg a kalóriákat tekintve a világ élelmiszertermelése általában véve lépést tart a növekvő népesség tápanyagigényével, addig több, mint 820 millió embernek nem jut elegendő ennivaló, még ennél is többen rossz minőségű táplálékot, vagy túl sok élelmiszert fogyasztanak. Az egészségtelen táplálkozás mára sokkal nagyobb megbetegedési és halálozási kockázatot jelent, mint a védekezés nélküli szexuális együttlét, az alkoholfogyasztás, a drog és a dohányzás okozta kockázat együttvéve.

A globális élelmiszertermelés egyaránt fenyegeti a klíma stabilitását, és az ökoszisztéma ellenálló képességét, valamint a legjelentősebb környezetei terheléssel bír, és a bolygó ökológiai határainak megsértésével fenyeget. Mindez komoly fenyegetést jelent, sürgősen szükség van tehát a globális élelmiszerrendszer radikális átalakítására. Alapvető cél, hogy a Föld egészsége étrend 2050-ig elérhetővé váljon 10 milliárd ember számára.

Az EAT-The Lancet-bizottság (továbbiakban Bizottság) erre a kritikus szükségletre válaszul összehívta 16 ország 37 különböző tudományterület vezető szakembereit - köztük az emberi egészség, a mezőgazdaság, a politika és a környezeti fenntarthatóság területéről -, hogy globális, tudományosan alátámasztott célokat fogalmazzanak meg az egészséges táplálkozással és a fenntartható élelmiszer-előállítással kapcsolatban. ${ }^{i v}$ Ez az első próbálkozás arra nézve, hogy mind a bolygó, mind a világ lakossága számára megfelelő egyetemes és tudományos élelmiszerrendszert alakítsanak ki.

Hatalmas munkát jelentett felmérni a különböző táplálkozási szokások környezeti hatásait. A növényi alapanyagokban gazdag, kevés állati összetevőt tartalmazó táplálék fogyasztása nemcsak, hogy megfelel az egészséges étkezés elvárásainak, hanem jó hatással van a természeti környezetünkre is. A szakirodalmi áttekintő tanulmány megállapítja, hogy ez az étkezési mód „win-win”, azaz mindkét fél számára előnyös helyzetet eredményez, vagyis mind az emberiség, mind a bolygó számára jó. Azonban még nincs globális konszenzus arról, hogy mi minősül egészséges táplálkozásnak és fenntartható élelmiszertermelésnek, valamint az is kérdéses, hogy a Föld egészsége étrend bevezetése 2050-ig elérhető cél-e.

A jelenleg rendelkezésre álló bizonyítékok értékelésével a Bizottság tudományosan megalapozott célokat fogalmazott meg az egészséges táplálkozás és a fenntartható élelmiszertermelés viszonylatában, valamint ezeket közös keretrendszerbe integrálta biztonságos múködési tér (safe operating space) néven. Így az élelmiszerrendszerek esetében azonosíthatóvá vált a Föld egészsége étrend (mind az emberi egészség, mind a fenntarthatóság szempontjából). ${ }^{\vee}$

Ezt a biztonságos múködési teret az egyes élelmiszercsoportok tudományosan meghatározott beviteli arányának figyelembevételével állapították meg (pl. gyümölcsfogyasztás 100-300 g/nap), így optimalizálva az emberi egészséget és a fenntartható élelmiszertermelést a stabil Föld-rendszerek biztosítására.

A tudományos célkitűzések meghatározták a táplálkozási rendszerek biztonságos múködési terét, melyek narancsszínúek az 1. ábrán. A körcikkek egyaránt mutatják a táplálkozási szokásokat és az élelmiszertermelést - függetlenül attól, hogy ezek teljesítik-e az emberi egészség vagy a környezeti fenntarthatóság kritériumait, vagyis akár kívül eshetnek a biztonsági múködési téren. Ezek a táplálkozási szokások az „egészséges, de nem fenntartható” (az emberiség számára előnyös, míg a bolygó számára hátrányos), az "egészségtelen és fenntartható” (hátrányos-előnyös), az „egészségtelen és nem fenntartható" (mind a bolygó, mind az emberiség számára hátrányos), valamint az „egészséges és fenntartható" (mindkét fél számára előnyös) kategóriákba sorolhatók.

\footnotetext{
iv Az EAT olyan, tudományos alapon múködő, globális nonprofit alapítvány, melynek célja a táplálkozási rendszer átalakítása.

${ }^{\vee}$ A Föld egészsége étrendjén értjük a humán civilizáció egészségét és a természeti rendszerek állapotát, amelytől az függ. Ezt a koncepciót 2015-ban vezette be a Rockefeller Alapítvány-The Lancet-bizottság, amikor a népegészségügy területét átalakították, mely hagyományosan csak az emberi egészségre fókuszált, nem vette figyelembe a természeti rendszereket. Az EAT-The Lancet-bizottság kialakította a bolygó egészsége koncepciót, és új fogalmat léptetett életbe: a Föld egészsége étrendet.
} 


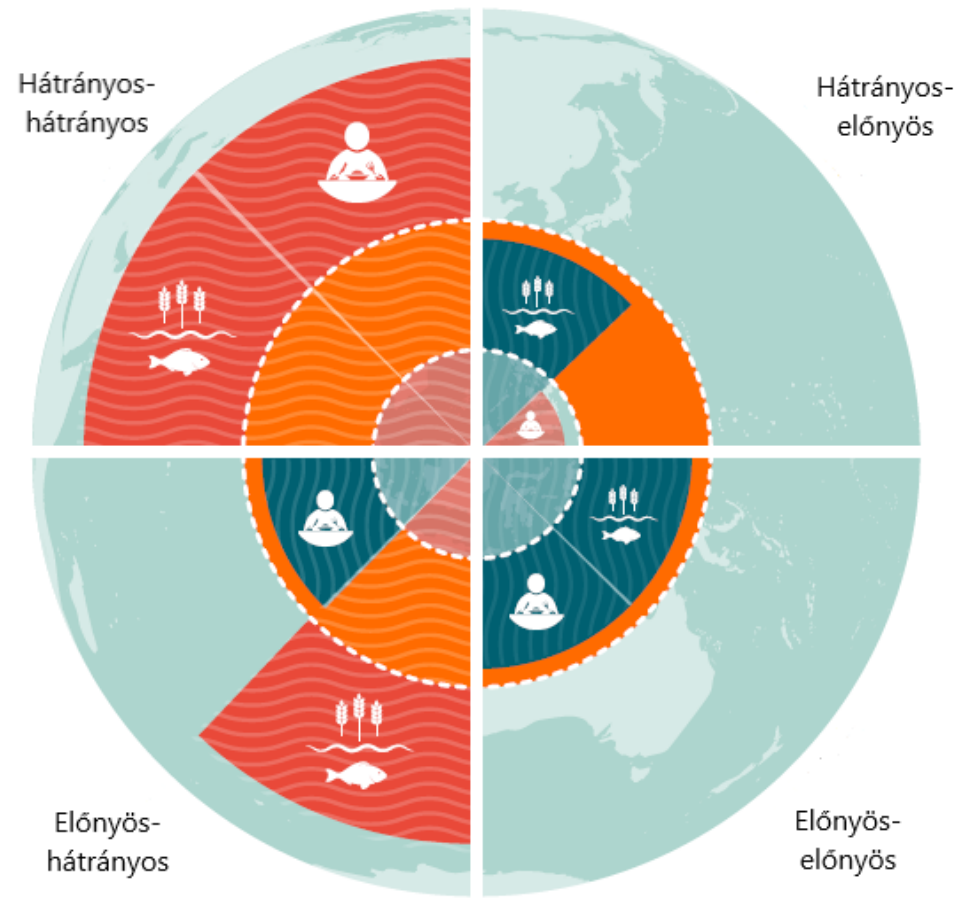

Forrás: az eredeti ábra magyar változata

A 2. ábrán látható Föld egészsége étrend tányérja a következőkből áll: a teljes mennyiség felét zöldségek és gyümölcsök teszik ki, a másik fele kalóriadús élelmiszerekből áll, mint teljes kiőrlésű gabonák, magvak, növényi fehérjeforrások, telítetlen növényi olajok, minimális hozzáadott cukor és mérsékelt mennyiségü állati fehérjék (minimális marha-, bárány-, disznó- és baromfihús, tojás, illetve hal).

Az egészséges táplálék optimális kalóriabevitelt biztosít és főként növényi alapú táplálékok széles választékából áll. Kevés állati eredetű táplálékforrást tartalmaz, inkább telítetlen, mint telített zsírok találhatóak meg benne. Ugyancsak korlátozott mennyiségű a finomított liszt, a magasan feldolgozott élelmiszerek aránya, valamint a hozzáadott cukor bevitele.

Bár a bolygó egészsége étrendjét követő táplálkozási mód (mely az egészséges táplálkozás alapelvein nyugszik) összhangban van a tradicionális táplálkozási szokásokkal, nem feltételezi, hogy mindenki pontosan ugyanazt fogja enni, nem ír elő pontos diétát. Ehelyett a Föld egészsége étrend azokat a tapasztalati táplálkozási csoportokat, táplálkozási szokásokat és ezekből kialakult diétákat körvonalazza, melyek optimalizálják az emberi egészséget. Az általánosan alkalmazásra javasolt Föld egészsége étrend javaslatnak helyi értelmezése, adaptációja szükséges, mely összhangban van a lokális kulturális, földrajzi, demográfiai, populációs és egyéni viszonyokkal.

A jelen táplálkozási szokásoktól az egészséges táplálkozás irányában való elmozdulásnak számos egészségelőnye lehet. A Bizottság háromféle megközelítésből elemezte az étrendváltozás hatását a táplálkozási betegségek okozta halálozásra. Mindhárom megközelítés megerősítette, hogy a jelenlegi táplálkozási szokásoktól az egészségesebb irányba történő elmozdulása jelentős egészségelőnyöket jelent. Évente kb. 11 millió korai halálesetet lehet így megelőzni, amely a felnőttek teljes halálozási mutatójának 19-24\%-a. 


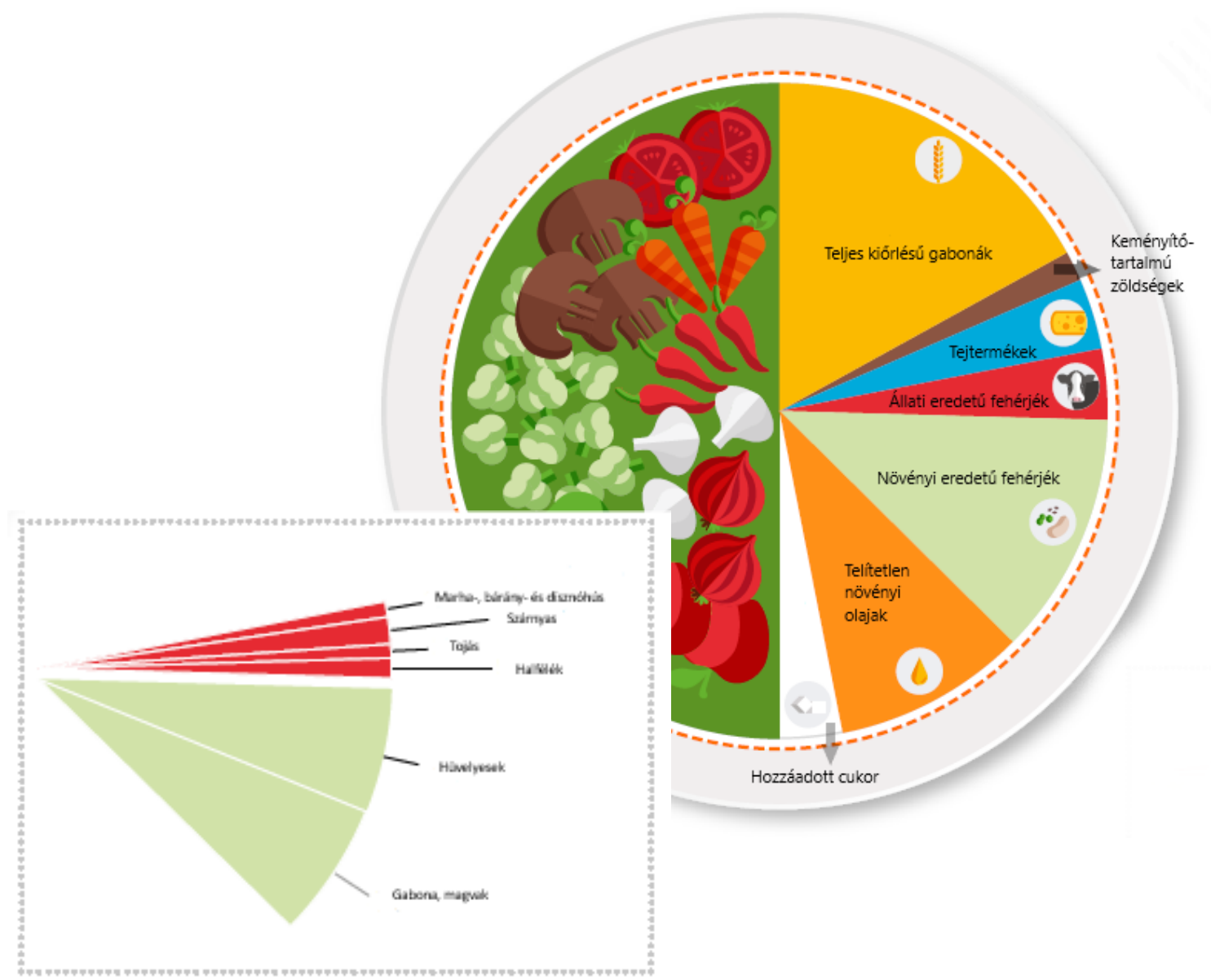

Forrás: az eredeti ábra magyar változata

Bolygónk állapotát a biológiai, valamint geofizikai rendszerek és folyamatok - különösen az éghajlati rendszerek és bioszféra közti kölcsönhatások szabályozzák.

A Bizottság ezek közül különösen 6 folyamatra fókuszált, melyek az élelmiszertermelést befolyásoló fő rendszerek és folyamatok: klímaváltozás, megmúvelt földterületek változása, ivóvíz-felhasználás, nitrogén- és foszforkörforgás, a biodiverzitás vesztesége. Ezek a rendszerek és folyamatok a szükséges paraméterek a fenntartható élelmiszertermelés meghatározásában. Ezek mindegyikében meghatározta a Bizottság azokat a határokat, melyeken belül maradva csökkenthető az egyébként visszafordíthatatlan és katasztrofális elmozdulás rizikója a földi rendszerben.
A Bizottság által megvizsgált és jelenleg könnyebben megvalósíthatónak látszó cselekvési lehetőségek a következők:

1. globális elmozdulás az egészségesebb élelmiszer-fogyasztás irányába,

2. fejlett élelmiszertermelési gyakorlatok,

3. az élelmiszerhulladék mennyiségének csökkentése.

Az elemzés azt mutatja, hogy a biztonságos múködési térben maradás az élelmiszerrendszertől egyidejűleg azt kívánja, hogy alapvető elmozdulás legyen a főként növényi alapú táplálkozás irányába, drámaian csökkenjen az élelmiszer-veszteség és -pazarlás, valamint jelentősen fejlődjön az élelmiszertermelés gyakorlata. Míg az elszigetelt akciók segítenek bizonyos határokon belül maradni, addig önmagában egyetlen beavatkozás nem elegendő ahhoz, hogy a biztonságos múködési tér összes határán belül maradjunk. 


\section{TANULSÁGOK HAZAI SZAKEMBEREK SZÁMÁRA}

A földi környezet fenntarthatósága és az emberi egészség megtartásának alapvető szempontjai egybeesnek, összhangban vannak. Közösen képesek biztosítani a földi élet, az ökoszisztéma egyensúlyát, amennyiben az ember képes komolyan venni ezeket a szempontokatés alkalmazkodni a tudományosan is meghatározható alapelvekhez, célokhoz. Ehhez azonban szemlélet- és tudatváltozásra van szükség. A természet- és társadalomtudomány területén dolgozó szakembereknek a következő évtizedekben minden lehetséges és hatékony eszközt be kell vetniük a társadalom táplálkozási és élelmiszer előállítási attitűdjének elmozdulásához. 